SECTION 21. Pedagogy. Psychology. Innovations in the field of education.

Koltsova Olga Sergeyevna

teacher,

Kherson state University, Kherson, Ukraine

\title{
THE ROLE OF PUBLIC ORGANIZATIONS IN THE DEVELOPMENT OF SOCIAL ACTIVITY OF YOUTH
}

The sharp reduction in the number of non-school establishments, sports facilities, etc. leads to the fact that most adolescents and youth are not included in the system of organized forms of leisure that is perceived mostly youth as the main sphere of activity.

Keywords: youth, society development.

\section{РОЛЬ ОБЩЕСТВЕННЫХ ОРГАНИЗАЦИЙ В РАЗВИТИИ СОЦИАЛЬНОЙ АКТИВНОСТИ МОЛОДЕЖИ}

Резкое сокращение количества внешкольных учреждений, спортивных объектов и т.п. приводит к тому, что большая часть подростков и молодежи не включены в систему организованных форм досуга, который воспринимается большей частью молодежи как основная сфера жизнедеятельности.

Ключевые слова: молодежь, общество, развитие.

Молодежь - наиболее динамичная социальная группа, проходящая стадию социализации, усваивающая общеобразовательные и профессиональные функции и подготавливаемая обществом к усвоению и выполнению социальных ролей взрослого [2, с. 46]. Основными составляющими социального портрета молодежи являются:

- возрастные границы возраста;

- специфика социального статуса;

- ролевые функции и особенности поведения;

- характеристики социально-демографической группы;

- социально-психологические характеристики;

- процесс социализации;

- самоидентификация и самоопределение [4].

Область культуры, досуга и творчества является для молодежи постоянной сферой социального участия и социального лидерства. Именно поэтому особенно важным является наличие условий для удовлетворения потребностей и интересов в сфере культуры, образования, искусства, 
спорта, туризма и отдыха. Одной из форм реализации этих потребностей и интересов являются общественные молодежные организации.

Молодежные общественные организации - объединения граждан, целью которых является осуществление и защита своих прав и свобод и удовлетворения политических, экономических, социальных, культурных и других общих интересов. Молодежные общественные организации создаются и действуют на основе принципов добровольности, равноправия их членов, самоуправления, законности и гласности $[5$, с. 5].

Сегодня молодежное общественное движение следует рассматривать как организованную социальную активность молодежи, различающуюся содержанием, направленностью деятельности, степенью их координированности.

Вопросами социально-культурной деятельности, а также поддержки молодежных и детских общественных объединений занимались Е.И. Григорьев [2], Т.Г. Киселѐва [1], Н.А. Шахина [5] и др. Исследования выявили, что в современном мире практически каждый человек может найти для себя интересующее направление общественной организации:

- культурная;

- рекреативная и спортивно-оздоровительная;

- социальная;

- правовая;

- межнациональная и межкультурная и др.

Мы считаем, что основными функциями молодежных общественных организаций являются:

- социально-адаптационная функция - создание условий для социализации личности, межличностного общения, ориентации личности в системе ценностей и т.д.;

- развивающая функция - создание условий для реализации личностного потенциала, развитие социальной активности, организационных и лидерских качеств, творческого мышления и т.д.

Анализ деятельности общественных организаций г. Херсона, как составной части системы воспитания, направленной на духовнонравственное развитие и самореализацию личности, профилактику девиантного поведения, предупреждение и преодоление вредных привычек, показал, что в течении учебного года они активно разрабатывают и принимают участие в организации и проведении воспитательных мероприятий, которые реализуются в процессе:

- внеурочной и внеклассной деятельности;

- внешкольного образования;

- работы органов ученического и студенческого самоуправления;

- взаимодействия с родителями, государственными учреждениями.

С целью проверки влияния общественных организаций на развитие социальной активности молодого поколения в начале учебного года нами 
были созданы экспериментальная (учащиеся школ, училищ и ВУЗов, которые входят в какую-либо общественную организацию) и контрольная группы (учащиеся школ, училищ и ВУЗов, которые не входят в общественные организации).

Социальная активность контрольной и экспериментальной групп определялась с помощью процентного распределения позиций относительно участия в воспитательных мероприятиях и общественной жизни на протяжении учебного года (табл. 1). Отметим, что под активной позицией мы понимаем непосредственное участие в организации и проведении мероприятий, под пассивной - участие в мероприятиях в качестве зрителей или группы поддержки.

Таблица 1

Распределение позиций учащихся в воспитательных мероприятиях

\begin{tabular}{|c|c|c|c|c|c|c|c|c|}
\hline \multirow{3}{*}{ Позиция } & \multicolumn{4}{|c|}{$K \Gamma(n=62)$} & \multicolumn{4}{|c|}{$Э Г(n=62)$} \\
\hline & \multicolumn{2}{|c|}{$\begin{array}{c}\text { Мероприяти } \\
\text { я учебных } \\
\text { заведений }\end{array}$} & \multicolumn{2}{|c|}{$\begin{array}{c}\text { Городские } \\
\text { мероприяти } \\
\text { я }\end{array}$} & \multicolumn{2}{|c|}{$\begin{array}{c}\text { Мероприят } \\
\text { ия учебных } \\
\text { заведений }\end{array}$} & \multicolumn{2}{|c|}{$\begin{array}{c}\text { Городские } \\
\text { мероприяти } \\
\text { я }\end{array}$} \\
\hline & n & $\%$ & n & $\%$ & $\mathbf{n}$ & $\%$ & $\mathbf{n}$ & $\%$ \\
\hline Активная & 12 & 19,4 & 6 & 9,7 & 46 & 74,2 & 32 & 51,6 \\
\hline Пассивная & 50 & 80,6 & 18 & 29,0 & 16 & 25,8 & 21 & 33,9 \\
\hline $\begin{array}{l}\text { Не } \\
\text { принимают } \\
\text { участия }\end{array}$ & - & - & 38 & 61,3 & - & - & 9 & 14,5 \\
\hline
\end{tabular}

Результаты, изложенные в табл. 1, показывают, что учащиеся экспериментальной группы проявляют большую активность в воспитательных мероприятиях, а именно 74,2\% занимают активную позицию участников мероприятий в учебных заведениях и $51,6 \%$ в городских мероприятиях. $\mathrm{B}$ пассивной позиции участников воспитательных мероприятий в учебных заведениях находятся $25,8 \%$ и $33,9 \%$ в городских мероприятиях. Также, анализ результатов показал, что только $14,5 \%$ экспериментальной группы не участвуют в городских мероприятиях, в учебных заведениях по данной позиции таких учащихся не наблюдалось.

Анализируя процент участия в воспитательных мероприятиях контрольной группы (табл. 1), понимаем, что они проявляют значительно меньшую активность, чем экспериментальная группа, а именно только $19,4 \%$ учащихся активно участвуют в мероприятиях в учебных заведениях и 9,7\% в городских мероприятиях. Относительно пассивной позиции участников воспитательных мероприятий результаты распределились следующим образом: в учебных заведениях пассивную позицию занимают 
$80,6 \%$ и $29,0 \%$ в городских мероприятиях. Полученные результаты также свидетельствуют, что 61,3\% контрольной группы вообще не участвуют и не интересуются городскими воспитательными мероприятиями, в учебных заведениях по данной позиции таких учащихся также не наблюдалось.

Исходя из результатов исследования, можно сделать вывод, что общественные организации выступают в качестве одной из самых динамичных организационных форм, выражающей интересы отдельных социальных групп. Направления и методы деятельности общественных организаций способствуют развитию социальной активности личности, формированию социальных отношений, созданию прочной коллективной идентичности.

\section{Литература}

1. Киселѐва Т.Г. Социально-культурная деятельность / Т.Г. Киселѐва, Ю.Д. Красильников. - М.: МГУКИ, 2004. - 539 с.

2. Павловский В.В. Социология молодежи и ювенология / В.В. Павловский // Социс. -1999. - №5. - С. 46-52.

3. Современные технологии социально-культурной деятельности: учеб. пособие / отв. ред. Е.И. Григорьева. - Тамбов: Изд-во ТГУ им. Г.Р. Державина, 2004. -504 с.

4. Социология молодежи: Учебное пособие / Под ред. проф. Ю.Г. Волкова. - Ростов-н/Д.: Феникс, 2001. - 576 с.

5. Шахина Н.А. Правовое регулирование государственной поддержки молодежных и детских общественных объединений системный подход в социальной работе / Н.А. Шахина. - М.: СОЮЗ, 1997. $-155 \mathrm{c}$. 